Kljucnikov, A., Sobekova Majkova, M., \& Vincurová, Z. (2018). Credit standards and factors affecting their strictness in the segment of SMEs in the Slovakia. Journal of International Studies, 11(1), 163-176. doi:10.14254/2071-8330.2018/11$1 / 12$

\title{
Credit standards and factors affecting their strictness in the segment of SMEs in the Slovakia
}

\author{
Aleksandr Kljucnikov \\ Faculty of Economics and Business, Pan-European University in \\ Bratislava \\ Slovakia \\ kliuchnikov@gmail.com
}

\author{
Monika Sobekova Majkova \\ Faculty of Economics and Business, Pan-European University in \\ Bratislava \\ Slovakia \\ monika.majkova@centrum.sk

\section{Zuzana Vincurová} \\ Faculty of Economics and Business, Pan-European University in \\ Bratislava \\ Slovakia \\ zuzana.vincurova@paneurouni.com
}

Abstract. Credit standards have a strong impact on GDP and the average size of provided loans within the economy. The aim of this paper is to investigate whether such factors as the age of entrepreneurs and the size of their companies are relevant, and have a significant impact on the perception of credit standards. The research is focused on the impact of the selected factors and comparison of the perception of strictness of credit conditions before and after the crisis on the basis of the data from two surveys carried out among 756 Slovak companies back in 2008 and then in 2016. Basing on the Pearson's chi-square analysis of the results we may present the statistical evidence that the age of an owner and the size of a company have significant impact on the perception of loan criteria, while the impact of company's size has higher intensity.

Keywords: small and medium-sized enterprises, SMEs, credit risk, credit standards, loan condition

JEL Classification: G11, G32 


\section{INTRODUCTION}

Occurrence of a financial crisis is always interconnected with changes in banks' behaviour along with the tendency of their credit standards' tightening with the aim to lower their level of credit risk (Nuhiu et al., 2017). Analysis carried out by the National Bank of Slovakia (NBS, 2015) has also confirmed that tightening of credit conditions has its significantly negative impact on GDP, on the extent of bank loans' granting, and, as a follow-up, it worsens SMEs financing possibilities. Bank financing is one of the most usual external source of financing for SMEs and the crucial means of support for their growth (Mercieca et al., 2009; Bena \& Ondko, 2012; Gambini \& Zazzaro, 2013, etc.). Making credit standards stricter builds the strong barrier for doing business that could have its impact on a number of SMEs and also on the growth of the already existing businesses (Majkova, 2008; Korcsmáros et al., 2016; Koisova, Habanik, Virglerova \& Rozsa, 2017). SMEs are the backbone of each market economy and economists consider them to be the most important components of every market economy in the world (Ivanová, 2017; Rahman et al., 2016; Adamowicz \& Machla, 2016; Badulescu, 2012; Belás \& Sopková, 2016; Dubravska et al., 2015; Henderson \& Weiler, 2010; Karpak \& Topcu, 2010; Spoz, 2014; Delibasic, 2016; Draskovic, Popov \& Peleckis, 2017 etc.). It is obvious, that analysis of credit risk and of the factors determining it would be important for a wide number of professional readers.

The aim of this paper is to investigate whether such factors as the age of entrepreneurs and the size of their companies are relevant, and are having a significant impact on the perception of credit standards. The research is focused on the level of impact from the selected factors and the comparison of the perception of strictness of credit conditions before and after the crises using the data of two surveys carried out among Slovak companies back in 2008 and then in 2016.

\section{LITERATURE REVIEW}

As it was presented in the introduction of this paper, the importance of SMEs for every market economy (Virglerova et al., 2016; Kot, 2017) can hardly be underestimated, while an external bank financing is necessary for their sustainable growth. SMEs have special characteristics that predetermine their problems with an access to finance, and the size of a company could be considered for one of the main factors that determine their financial and credit risks. External financing is a current issue especially in case of the companies, operating on the emerging and developing markets. Although SMEs ensure a significant part of employment in most of the countries with market economies (Simo et al., 2016), a various number of existing obstacles slow down or even, in some cases, prevent their economic growth (Beck \& Demigruc-Kunt, 2006; Dobes et al., 2017, Ključnikov \& Belás, 2016). Limited access to external financing and bank loans is one of these obstacles (Abor et al., 2014; Dong and Men, 2014). Lack of finance is considered to be the main problem for the growth of SMEs (Steinerowska-Streb \& Steiner, 2014; Kozubíkova et al., 2015, 2017; Meyer \& Meyer, 2017).

A possibility of potential tightening of the credit standards of bank loans is a part of a credit risk. The stricter the loan criteria are, the more difficult it is for SMEs to get an access to external finance. We consider a loan maturity, loan conditions (history, financial indicators, etc.), collaterals, a size of a loan, a margin on risk loans, etc. for the credit standards or loan criteria. The paper is focused on the impact of two factors, interconnected with obtaining of bank loans - firm's size and the age of an owner.

\section{The impact of firm's size on SMEs crediting in Europe}

Many studies from around the world present the evidence that the size of a company has a significant impact on company's finance in general, and on credit financing in particular. The studies usually confirm that smaller firms use external bank financing to a lesser extent than larger companies, but external finance 
is still an important financial source for them due to its impact on their growth (Beck et al., 2008; Mercieca et al., 2009; Bena \& Ondko, 2012; Beck \& Demigruc-Kunt, 2006; Klierova \& Kutik, 2017, etc.). Gambini and Zazzaro (2013) declare that bank lending has a positive effect on the growth of the companies. According to Behr and Guttler (2007) bank financing is the dominant source of external finance used by the SMEs in Germany. Smaller and younger companies are facing more severe financing constraints in comparison to older and larger companies. The availability of credit information and the bank concentration ratio have a significant impact on the financing of SMEs (Dong and Men, 2014).

During the crisis when the banks tightened their credit standards (Sobekova Majkova, 2011, 2016) the problems of SMEs with the bank financing emphasised. Overdraft facilities, that are a significant supportive option for SMEs export activities financing, especially on the developing and emerging markets, had also changed policies of providing loans during the financial crisis (Jinjarak and Wignaraja, 2016). Unlike large companies, SMEs do not usually have the sufficient collateral for getting bank loans, and this fact indicates that the size of a company may be an important factor in an assessment of the credit risk (Irwin and Scott, 2010). 3/4 of the entrepreneurs in the segment of SMEs in the Czech Republic perceive the intense action of the financial risk (Belás et al., 2015b.).

Weak capital power and the degree of credit worthiness belong to the most significant problems in SME financing (Cheng and Tang, 2012; Shi, 2012; Sobekova Majkova, 2016). It was proved that small and growing firms in the UK are likely to have higher credit interest rates than large firms. Firm's size has also an impact on the bank financing in the Great Britain (Rostamkalaei \& Freel, 2015), where it affects the values of interest rates on provided loans. The smaller the firm is, the higher the interest rates are. The study by Oliveira and Fortunato (2006) also confirms that the size of a company is a relevant factor affecting credit finance. According to their study the problems with the credit rejection or high interest rates are the most common for small firms. Firm's size and age, as well as the age of the entrepreneur, influences potential financing options of the company. Researches declare that smaller and younger firms have more limited possibilities of an external financing than larger and older firms (Bottazzi, et. al., 2014) and also that firm's size matters in its relationship with the banks (Bougheras et al., 2006). Firm's size is considered as a relevant factor that has an impact on the access to finance. SMEs with more innovative products are less probable to be successful in credit facilities than their competitors with less innovative or ordinary products (Freel, 2006).

\section{The impact of firm's size on SMEs crediting in Slovakia}

Slovak researchers declare the problem with an insufficient financing to be one of the barriers for young entrepreneurs in Slovakia (Jakubec et al., 2012). In observing of the impact of the firm's size on bank financing they provide the results conformal with the results of the foreign researches. Domestic SMEs mostly use the internal financial sources. The usage of the bank loans is substantially less frequent due to the problem with the collateral (Sobekova Majkova, 2011). The economic crisis has reduced the profitability of SMEs in Slovakia (Belas et al. 2015a) and the Czech Republic. The entrepreneurs in the study by Belas et al. (2014), stated that the financial risk is the most important type of business risks.

\section{The impact of age on SMEs crediting}

The impact of owner's age on the credit risk was researched by several authors. Younger and less educated entrepreneurs are more likely to use external finance to support the growth of their businesses, while older and more educated entrepreneurs are less likely to use external financing. The options of external financing are more limited for the younger companies in comparison to the older ones.

Young entrepreneurs present a lack of entrepreneurial competencies in comparison with older and more mature businessmen, while the age is one of the factors directly related the growth of their 
competencies (Vos et al., 2007; Bottazzi et al., 2014). Younger entrepreneurs are more likely to pay higher interest rates due to the smaller size of their businesses, and their ability to pay on time is lower than of the older entrepreneurs (Lazányi, 2014). Younger entrepreneurs are more sensible to the financial restraints than larger and older firms. They face more severe constraints in a process of an approval of bank loans and in an overall access to finance, what can lead to the deceleration of their growth (Oliveira and Fortunato, 2006; Dong and Men, 2014). The impact of age on the level of company's credit risk was also confirmed by several scientific studies, that proved the fact that younger entrepreneurs are facing the credit risk more intensively (Hernández-Cánovas \& Martínez-Solano, 2010; Bougheas et al., 2006; Pickernell et al., 2011; Riding et al., 2012). The age of the company has an impact on the perception of credit risk's importance (Belas et al., 2016).

The impact of age of the entrepreneur on the financial risk is not always confirmed. According to Slavec (2014) the age is not negatively related to the access to bank loans or trade credit in Slovenian business environment, while the level of education has a more significant impact on the access to the bank loans than the age of entrepreneurs (Slavec, 2014).

\section{METHODOLOGY}

\section{The selected sample and data collection process}

According to the newest official Slovak statistical data, the total number of business units in Slovakia is $555314.99 .8 \%$ of them (554 743) belong to the category of SMEs. The most dominant group of business units belong to the category of micro enterprises with $0-9$ employees $(96.9 \%$ on the total number of legal entities), followed by the small $(2.5 \%)$, medium $(0.50 \%)$ and large $(0,1)$ enterprises.

Our research focused on the actual situation in the Slovak business environment was carried out in 2016 through the quantitative scientific method of the questionnaire survey. The research data were collected by three specific ways. Selected companies were contacted by our research team by email. In case that the selected company had not replied on the email, the company was contacted by phone. The questionnaire was also placed on the specialized economic web-portals, focused on SMEs. The total number of 438 questionnaires was collected during the research. $93.8 \%$ of the respondents represented the companies from SME segment.

The data from the research carried out in 2008 among the Slovak companies were used to compare the achieved results in the selected fields of the research. The data sample in the second research included 308 companies (Sobekova Majkova, 2011).

The shares of the other types of the companies in the basic data set, and the structure of representatives of the specified categories of enterprises among the respondents of our survey carried out in 2016 are presented in Table 1.

Table 2 shows the comparison of the regional structure between the basic file and the selected sample (the differences are specified in \%). The values of the differences in all the categories reach the values in an approximate range of $2-4 \%$, with the exception of Bratislava and Košice region.

According to the comparison of the data from the basic data set and the selected sample in relation to the area of economic activity we can state that the differences between the basic data set and the selected sample are negligible (up to $5 \%$ ). The comparison is presented in Table 3. 
Table 1

The number of the entrepreneurs in Slovakia in 2014 (the basic data set and the selected sample)

\begin{tabular}{|c|c|c|c|c|}
\hline Legal Form (2014) & \multicolumn{2}{|c|}{ Basic data set } & \multicolumn{2}{c|}{ Selected sample } \\
\cline { 2 - 5 } & Total values & Share (\%) & Absolute values & in \% \\
\hline $\begin{array}{c}\text { Micro enterprises (0-9 emp.) } \\
\text { and individual entrepreneurs }\end{array}$ & 538330 & $96.9 \%$ & 287 & $65.6 \%$ \\
\hline Small enterprises (10-49 emp.) & 13743 & $2.5 \%$ & 95 & $21.7 \%$ \\
\hline Medium enterprises (50-249 emp.) & 2661 & $0,50 \%$ & 29 & $6.6 \%$ \\
\hline Large enterprises (250+ emp.) & 580 & $0.1 \%$ & 27 & $6.2 \%$ \\
\hline Total number of business units & 555314 & $100 \%$ & 438 & $100 \%$ \\
\hline SMEs from total & 554743 & & 411 & \\
\hline Share of SMEs in \% & $\mathbf{9 9 . 8 \%} \%$ & & $\mathbf{9 3 . 8 \%}$ & \\
\hline Young entrepreneurs up to 35 year old* & $28.1 \%$ & & $37.2 \%$ & \\
\hline
\end{tabular}

Source: Company register of the Statistical office of Slovakia, own processing

*Young entrepreneur data 2012

Table 2

Comparison of the regional structure (the basic data set and the selected sample)

\begin{tabular}{|c|c|c|c|c|}
\hline \multirow{2}{*}{ Region } & \multicolumn{2}{|c|}{ Selected sample } & Basic data set* & Difference \\
\cline { 2 - 5 } & Number of respondents & $\mathbf{\%}$ of respondents & $\begin{array}{c}\text { Number of } \\
\text { respondents }\end{array}$ & $\begin{array}{c}\text { \% of } \\
\text { respondents }\end{array}$ \\
\hline Bratislava & 199 & $45.4 \%$ & $34,70 \%$ & $10.7 \%$ \\
\hline Trnava & 28 & $6.4 \%$ & $9.2 \%$ & $-2.8 \%$ \\
\hline Nitra & 34 & $12.3 \%$ & $10 \%$ & $2.3 \%$ \\
\hline Trenčín & 44 & $10 \%$ & $8.3 \%$ & $1.7 \%$ \\
\hline Žilina & 56 & $12.8 \%$ & $9.4 \%$ & $3.4 \%$ \\
\hline Banská Bystrica & 20 & $4.6 \%$ & $8.8 \%$ & $-4.2 \%$ \\
\hline Prešov & 21 & $4.8 \%$ & $9.2 \%$ & $-4.4 \%$ \\
\hline Košice & 16 & $3.7 \%$ & $10.3 \%$ & $-6.6 \%$ \\
\hline
\end{tabular}

Source: National Agency for the Development of SMEs, 2012

Table 3

Numbers of companies in Slovakia according the area of economic activity (the basic data set and the selected sample)

\begin{tabular}{|c|c|c|c|c|}
\hline \multirow{2}{*}{ Field of doing business } & \multicolumn{2}{|c|}{ Selection file } & Basic file* & Difference \\
\cline { 2 - 5 } & Count of respondents & \% respondents & \% companies & \% companies \\
\hline Production & 43 & $9.8 \%$ & $12.5 \%$ & $-2.7 \%$ \\
\hline Trade & 98 & $22.4 \%$ & $25.2 \%$ & $-2.8 \%$ \\
\hline Agriculture & 20 & $4.6 \%$ & $4.5 \%$ & $0.1 \%$ \\
\hline Construction & 57 & $13 \%$ & $16.5 \%$ & $-3.5 \%$ \\
\hline Services & 165 & $37.8 \%$ & $34.5 \%$ & $3.3 \%$ \\
\hline Transport & 18 & $4.1 \%$ & $3.2 \%$ & $0.9 \%$ \\
\hline Other & 36 & $8.2 \%$ & $3.6 \%$ & $4.6 \%$ \\
\hline
\end{tabular}

Source: National Agency for the Development of SMEs, 2012 
The results of verification of the selected sample, presented in Tables 1, 2 and 3, confirm that the structure of the sample is virtually identical with the basic data set.

\section{Research methodology and the definition of the alternative hypotheses}

The presented research involved several quantitative scientific methods, including the questionnaire survey, statistical analysis by the tools of descriptive statistics (averages and percentages), application of the methods of comparison and deduction in data analysis. Microsoft Excel (Office 2007) software was used as the important tool for data analysis due to its possibilities in data processing using the pivot tables. The statistical method of Pearson's chi-square was applied for the verification of an existence of statistically significant dependencies and differences between the selected factors at the significance level of $5 \%$. The research team has also applied the qualitative method of individual interview with the owners or relevant employees in relation to the needs of the research. The interviews were conducted at the appropriate level of deepness either in person, or in some cases via telephone or email.

Using the method of an expert estimation, the research team defined three alternative working hypotheses $(\mathrm{H} 1-\mathrm{H} 3)$ related to the chosen factors. The hypotheses were set in relation to the age of the owner (a) and the size of the company (b):

H1: The age of the owner (a)/ the size of the company (b) has an impact on the opinion that credit criteria are too difficult to fulfil.

H2: The age of the owner (a)/ the size of the company (b) has a significant impact on the opinion that better knowledge of loan criteria can ease SMEs access to bank financing.

H3: There is a statistically significant dependence between the age of the owner (a)/the size of the company (b) and the selection of the strictest loan criterion.

\section{EMPIRICAL RESULTS AND DISCUSSION}

An opinion that the credit criteria are too difficult for SMEs is quite popular among the experts on this group of enterprises. The banks usually request a provision of a high level of collateral, demonstration of quite a long company's history, a positive performance and sustainable financial indicators from the loan candidates.

Table 4

Pearson's chi-square calculation according to the age of the owner

\begin{tabular}{|c|c|c|c|c|c|c|c|c|}
\hline \multirow{2}{*}{$\begin{array}{l}\text { Credit } \\
\text { standard } \\
\text { s are } \\
\text { very } \\
\text { strict }\end{array}$} & \multicolumn{2}{|r|}{ Agree } & \multicolumn{2}{|r|}{ Disagree } & \multicolumn{2}{|c|}{ Neutral position } & \multicolumn{2}{|c|}{ Total } \\
\hline & $\%$ & $\begin{array}{l}\text { absolute values } \\
\text { (AV) and chi- } \\
\text { square subtotals }\end{array}$ & $\%$ & $\begin{array}{l}\text { absolute values } \\
\text { and chi-square } \\
\text { subtotals }\end{array}$ & $\%$ & $\begin{array}{c}\text { absolute values } \\
\text { and chi-square } \\
\text { subtotals }\end{array}$ & $\%$ & AV \\
\hline $\begin{array}{ll}\text { To } & 35 \\
\text { years } & \\
\end{array}$ & 53.37 & 87 (100.48) [1.81] & 15.95 & $26(27.17)[0.05]$ & 30.67 & $50(35.35)$ [6.07] & 100.00 & 163 \\
\hline $\begin{array}{l}36-45 \\
\text { years }\end{array}$ & 65.79 & $75(70.27)[0.32]$ & 17.54 & $20(19.00)[0.05]$ & 16.67 & 19 (24.73) [1.33] & 100.00 & 114 \\
\hline $\begin{array}{l}46 \text { and } \\
\text { more }\end{array}$ & 67.08 & $108(99.25)[0.77]^{1}$ & 16.77 & $27(26.83)[0.00]$ & 16.15 & $26(34.92)[2.28]$ & 100.00 & 161 \\
\hline Total & - & 270 & - & 73 & - & 95 & 100.00 & $438^{2}$ \\
\hline
\end{tabular}

Source: own processing

${ }^{1}$ Subtotals of chi-square calculation from online statistical software

${ }^{2}$ Grand total in chi-square calculation 
The first part of our research was devoted to the investigation whether the age of the owner has a significant impact on the perception of the level of strictness of the credit standards in case of SMEs. In the percentage evaluation of the perception of different groups of respondents $(n=438)$ we observed that older entrepreneurs agree with this opinion more often in comparison to younger entrepreneurs. The age groups of young, middle age and old entrepreneurs were formed in order to divide the respondents into groups with the similar characteristics at the base of their age. The first group included the respondents aged up to 34/35 years, because the relevant institutions ${ }^{3}$ consider this level of age as the limit for the inclusion to the group of young entrepreneurs. At the base of an expert estimation of the research team members the rest of entrepreneurs were divided into two groups with the age below or above 45/46 years (middle aged and older entrepreneurs). The results of our calculations, presented in Table 4, confirm the validity of a partial hypothesis $\mathrm{H1}$ a, stating the existence of the statistically significant dependence between the age of the owner and the opinion that credit criteria are too difficult to fulfil. The value of chi-square statistic is $\chi^{2}=12.674=\chi^{2} 0.05$ with 4 dgf $^{4}$. $P$-value of 0.012984 indicates that the result is significant at $p<0.05$. This fact allows us to confirm our alternative working bypothesis $\mathrm{H} 1 \mathrm{a}$ at the level of probability of $95 \%$.

Firm's size was the next researched factor with a potential impact on the perception of credit standards. We assumed that smaller companies more intensively perceive the credit standards as strict in comparison with the larger companies. It might be quite difficult for the smaller companies to fulfil the credit criteria because they do usually have the problems with a weak capital power and a short history of the company. Application of the selected statistical methods on the researched data sample confirmed our partial hypothesis about the existence of a statistically significant dependence between firm's sized and the opinion that credit criteria are too difficult to fulfil. The value of chi-square statistic is $\chi^{2}=16.6106=\chi^{2} 0.05$ with 6 dgf. $P$-value of 0.010826 indicates that the result is significant at $p<0.05$. This fact allows us to confirm our working alternative bypothesis $\mathrm{H} 1 \mathrm{~b}$ with $95 \%$ level of probability.

In order to trace the perception of the development of credit standards in Slovakia we used the data from the research carried out among Slovak SMEs in $2008(n=308)$ in time just before the beginning of the financial crisis. The respondents had a possibility to describe the perception of credit standards on the scale from 1 (not difficult) to 7 (very difficult), when the value of 4 meant the medium strictness of the credit standards. We merged the respondents into two groups, perceiving the credit standards as very difficult ( $5-7$ points) or quite easy ( $1-3$ points).

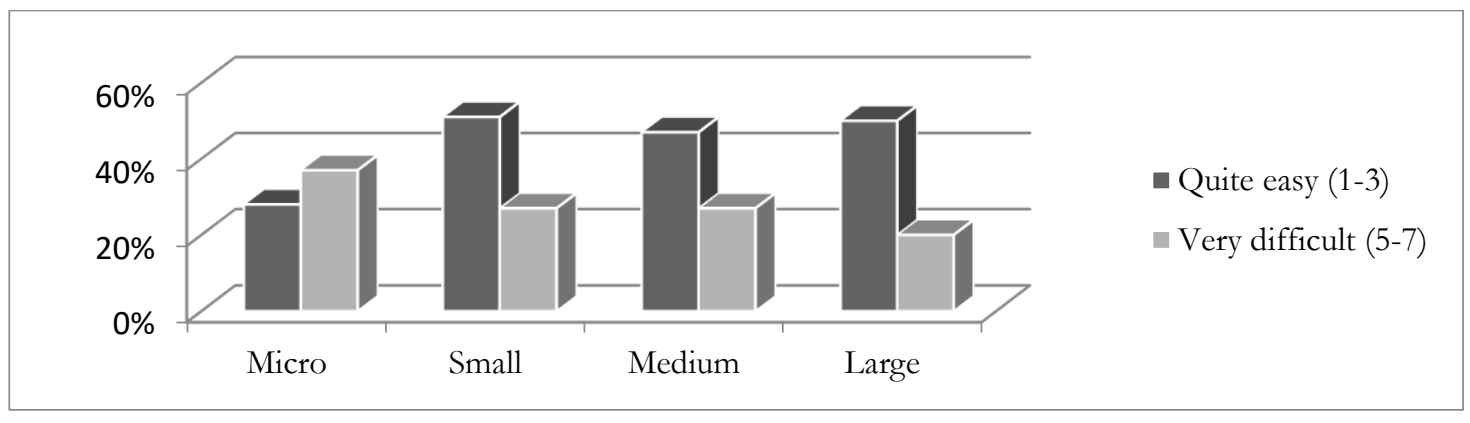

Figure 1. Perception of the difficulty of credit standards in \%

Source: Majková, 2008

3 Association of Young Entrepreneurs, Slovak Statistic Bureau, etc.

${ }^{4}$ Degrees of freedom 
The data, presented in Figure 1, confirm our partial hypothesis about the statistically significant dependence between the size of the company and the perception of the difficulty of the credit standards. Smaller companies present the opinion that credit standards are strict more intensively in comparison with the larger companies. Value of chisquare statistic is $\chi^{2}=11.948=\chi^{2} 0.0025$ with 4 dgf. $P$-value is less than 0.025 . This fact allows us to confirm our working alternative hypothesis $\mathrm{H} 1 \mathrm{~b}$ with $97.5 \%$ level of probability.

The second part of the research is focused on the impact of the age of the owner and the size of the company on the opinion that better knowledge of loan criteria can ease SMEs access to bank financing. Our results bring an interesting finding in relation to the age of the owner. The value of chi-square statistic is $\chi^{2}=8.5786=\chi^{2} 0.05$ with 4 dgf. The $p$-value of 0.07254 indicates that the result is not significant at $p<0.05$, and due to this fact our working alternative hypothesis H2a is rejected. The age of the owner does not have any significant impact on the opinion that better knowledge of loan criteria can ease SMEs access to bank financing.

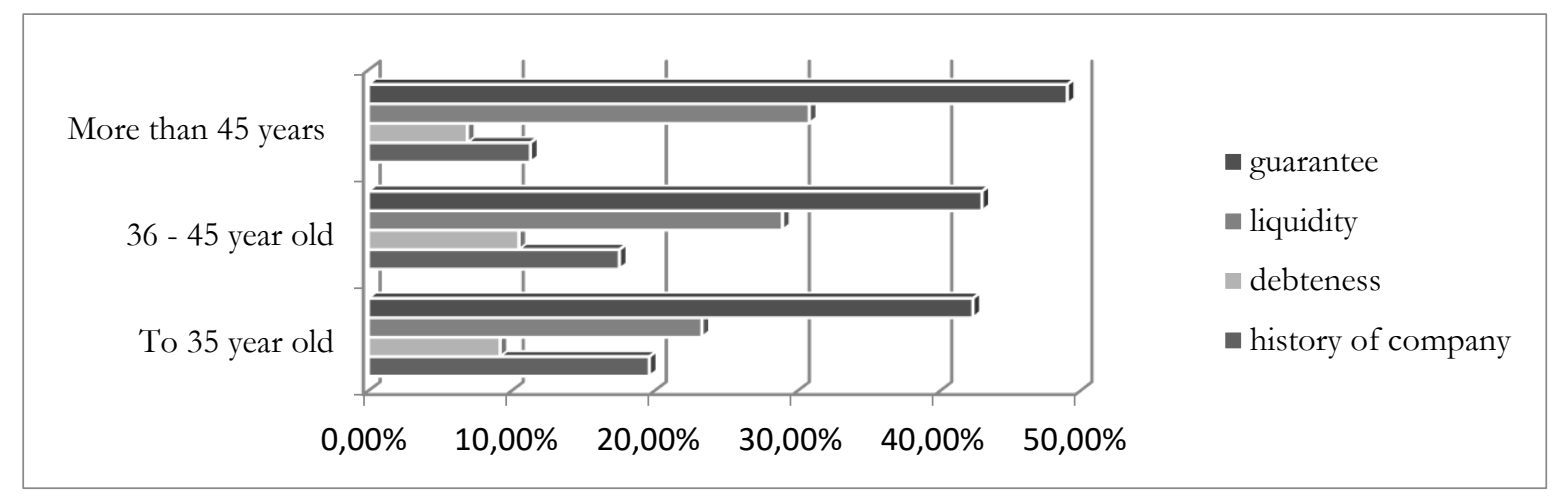

Figure 2. Number of answers on the question which loan criterion is the most difficult one (in \%) Source: own processing

The research of the impact of the company's size brought the opposite results. The calculated value of chi-square statistic is $\chi^{2}=16.0535=\chi^{2} 0.05$ with 6 dgf. The $p$-value of 0.001347 indicates that the result is significant at $p<0.05$. This fact allows us to confirm working alternative bypothesis $H 2 b$ with $99.86 \%$ level of probability.

The last part of the research was focused on the impact of owner's age and company's size on the selection of the strictest loan criterion. We found no statistically significant dependencies between the age of the owner and the selection of the strictest loan criterion. The lack of guarantees was identified as the most difficult problem for all observed age groups (Figure 2). The value of chi-square statistic is $\chi^{2}=$ $14.2513=\chi^{2} 0.05$ with 4 dgf. The $p$-value of 0.075445 indicates that the result is not significant at $p<0.05$, and therefore we have to reject working alternative hypothesis $\mathrm{H} 3 \mathrm{a}$. The situation in relation to the size of the company was different. $50.35 \%$ of micro and $43.62 \%$ of small enterprises declared the lack of guarantees as the most difficult criterion. Medium-sized enterprises declared the problem with the liquidity $(48.28 \%)$ and large companies declared the guarantees and liquidity $(29.63 \%)$ to be the most difficult criteria. 
Pearson's chi-square calculation according to the firm size

\begin{tabular}{|l|c|c|c|c|c|}
\hline $\begin{array}{l}\text { The most } \\
\text { difficult } \\
\text { criterion }\end{array}$ & History & Indebtedness & Liquidity & Guarantee & $\begin{array}{c}\text { Row } \\
\text { Totals }\end{array}$ \\
\hline Micro & $41(45.57)[0.46]$ & $20(24.74)[0.91]$ & $71(78.11)[0.65]$ & $144(127.58)[2.11]$ & 276 \\
\hline Small & $14(15.19)[0.09]$ & $10(8.25)[0.37]$ & $27(26.04)[0.04]$ & $41(42.53)[0.05]$ & 92 \\
\hline Medium & $9(4.79)[3.71]$ & $3(2.60)[0.06]$ & $14(8.21)[4.09]$ & $3(13.41)[8.08]$ & 29 \\
\hline Large & $6(4.46)[0.53]$ & $5(2.42)[2.75]$ & $8(7.64)[0.02]$ & $8(12.48)[1.61]$ & 27 \\
\hline $\begin{array}{l}\text { Column } \\
\text { Totals }\end{array}$ & 70 & 38 & 120 & 196 & 4245 \\
\hline
\end{tabular}

Source: own processing

The value of calculated chi-square statistic is $\chi^{2}=25.5244=\chi^{2} 0.5$ with 6 dgf. $P$-value of 0.002443 indicates that the result is significant at $p<0.05$ and allows to confirm working alternative bypothesis H3b.

The results of our research are conformal with the results of Irwin and Scott (2010), Sobekova Majkova (2011), Belás et al. (2015a), Cheng and Tang (2012), Shi (2012), Majkova (2008), Jinjarak and Wignaraja (2016), Rostamkalaei and Freel (2015), Oliveira and Fortunato (2006), Bottazzi, et. al. (2014), Bougheras et al. (2006) and Freel (2006). All presented authors state that firm's size is a significant factor in relation to an access to finance, to external bank financing and the credit risk.

In case of the impact of owner's age we can confirm, that it has statistically significant impact only on the opinion that the credit criteria are too difficult to fulfil. This result is conformal with the findings by Vos et al. (2007), Bottazzi et al. (2014), Lazányi (2014), Neuberger and Räthke-Döppner (2014), Oliveira and Fortunato (2006), Dong and Men (2014), Hernández-Cánovas and Martínez-Solano (2010), Bougheas et al. (2006), Pickernell et al. (2011) and Riding et al. (2012). These authors confirm that the age of the owner is a relevant factor influencing the money borrowing. In the second and third cases we had rejected alternative working hypotheses about the impact of age on credit criterions and confirm the results of Slavec (2014) that the age of the owner is not a relevant factor in bank financing.

Using the data from the researches carried out in 2008 and 2016 we bring the statistical evidence that the most vulnerable segment of SMEs - small enterprises with the short history - perceives that the credit standards in case of the bank loans in Slovakia are too strict. Analysis of the National Bank of Slovakia (2015) demonstrates the importance of credit standards, describes their influence on the economy and bank lending. According to their research the demand for loans rapidly decreased in the period between 2007 and 2009, when the banks significantly tightened the credit standards. A sign of revival of crediting of the SMEs segment appeared in 2014, that is especially evident in comparison with the negative tendencies in 2013 (Figure 3). The data presented in Figure 3 demonstrate a quite obvious correlation between the development of GDP and the provision of the bank loans.

\footnotetext{
${ }^{5}$ Smaller number of respondents replied to this question (424 from total 438).
} 


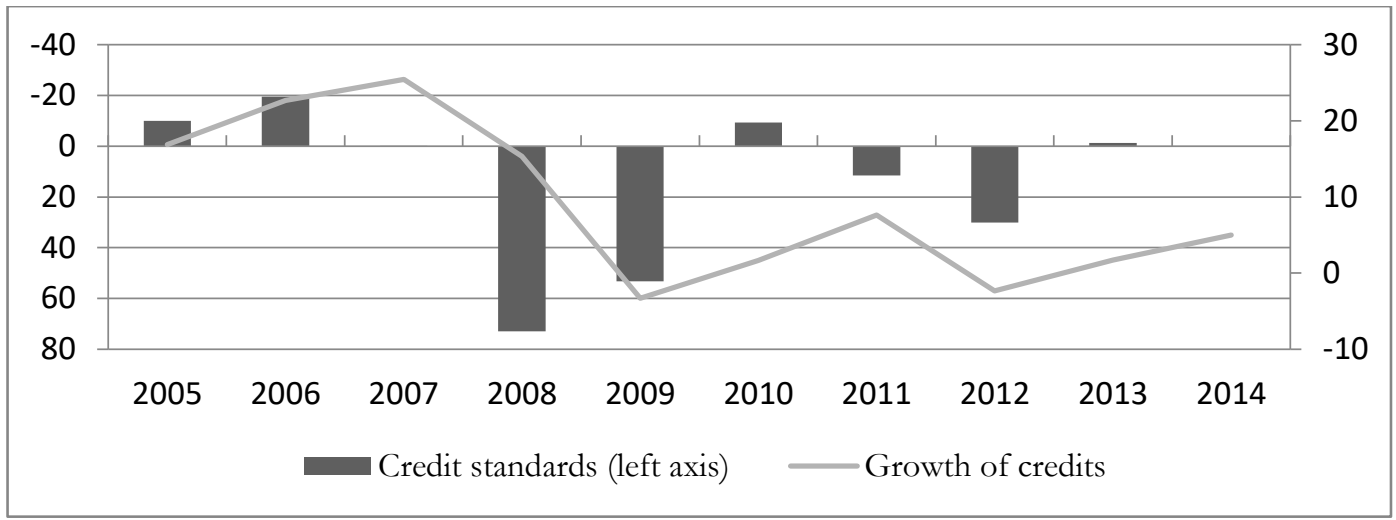

Figure 3. Correlation between the provision of bank loans to non-financial companies and the credit standards

Source: NBS, Analytical review, 2015

The credit standards where significantly tightened during the financial crises. Through the analysis of the state of the credit standards before and after the financial crisis we demonstrate the development in this area and its impact on Slovak SMEs. Our results are conformal with the analysis of the National Bank of Slovakia (2014) that declared the tightening of the credit standards - positive development on the left axis (negative development means the simplification of credit standards). As it is obvious from Figure 3 the tightening of the credit standards in 2008 was more intensive than in 2009, 2012 and 2011 (lower level of indicator means the tightening of credit conditions). This finding confirms the statement, that a tightening of the credit standards was accompanied by the drop in the amount of provided bank loans on Slovak financial market.

The National Bank of Slovakia (NBS, 2015) confirmed that the tightening of the credit standards has a negative impact on the economy and GDP, while the impact of this factor appears with a short delay (Figure 4). The NBS presents the finding that the impact on GDP was in the interval between 0.43 and 0.66 percentage points except for the case of the year 2009 when it reached a peak value of 1.5 (left axis of Figure 4). The lines on the chart in Figure 4 present the growth of GDP with and without the restrictions. According to the presented data the decline of GDP in 2009 would have been lower in case that the restriction would not be so strong. 


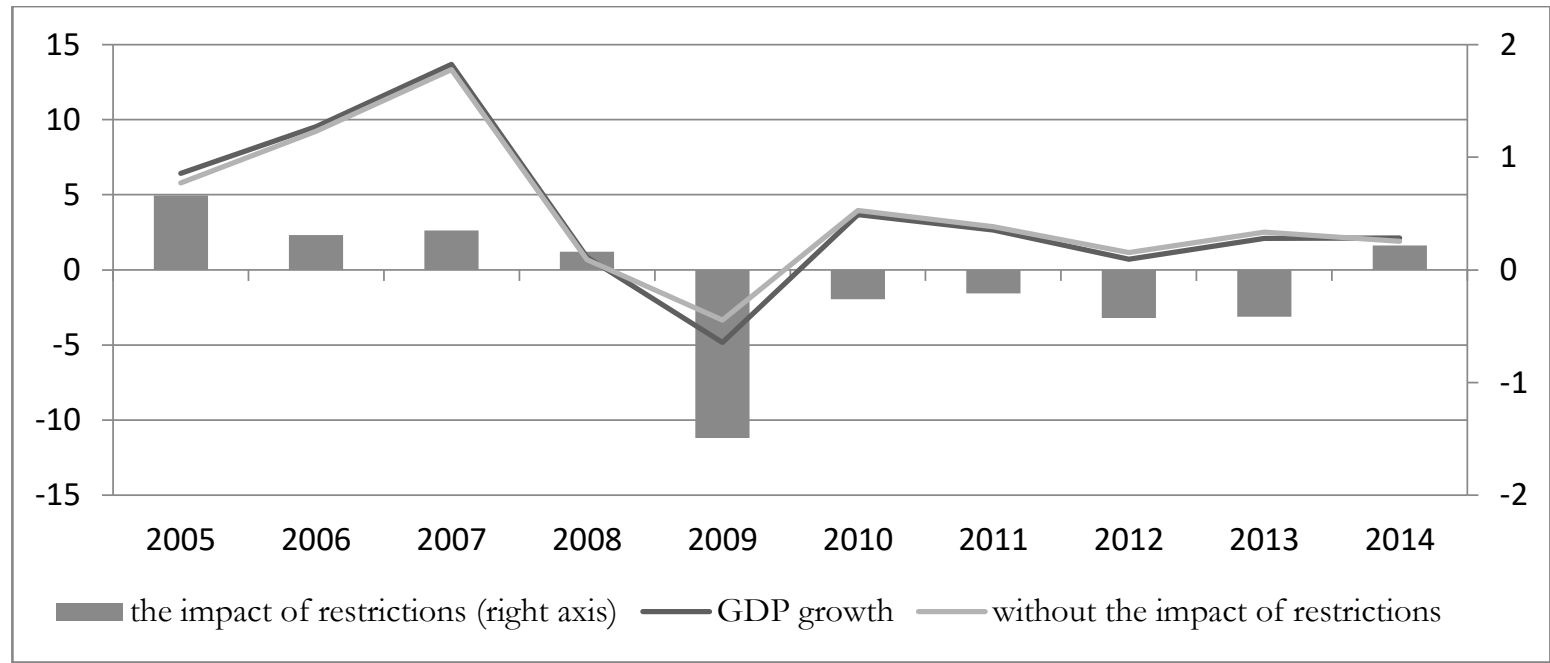

Figure 4. Estimation of the impact of tightening of the credit standards on GDP (\%, percentage points)

Source: NBS, Analytical review, 2015

\section{CONCLUSION}

Credit standards have a strong impact on GDP and the average size of provided loan in the economy. The aim of this paper was to investigate whether such factors as the age of an entrepreneur and the size of a company are relevant, and have a significant impact on the perception of credit standards. The research was focused on the level of impact of the selected factors and the comparison of the perception of strictness of credit conditions before and after the crisis at the base of the data of two surveys carried out among 756 Slovak companies in 2008 and 2016.

The analysis of the dependencies by the method of Pearson's chi-square statistics allow us to state that the size of a company is a more significant factor in relation to the credit financing of SMEs (the impact of the size of a company was confirmed in case of the hypotheses H1b, H2b, H3b), than the age of the owner (the impact of the age of the owner was confirmed only in case of the hypothesis H1a, in the other cases the impact was not identified).

We bring the statistical evidence that the age of the owner and the size of a company have a significant impact on the opinion that the credit criteria are too difficult to fulfil. We observed that older entrepreneurs agree with this opinion to a higher extent than their younger colleagues. Representatives of the smaller companies express the opinion that the credit standards are too difficult to a higher extent in comparison with the larger companies.

While our findings confirm the existence of the statistically significant impact of the size of a company on the opinion that a better knowledge of loan criteria can ease SME's access to bank financing, we were unable to find the evidence of the impact of the age of the owner on this opinion. We were also unable to find a statistically significant dependence between the age of the owner and the selection of the strictest loan criterion. The lack of guarantees was identified as the most difficult problem in case of all observed age groups. But only the size of a company was identified as a factor with a significant impact. While micro and small enterprises declared the lack of guarantees to be the strictest criterion, mediumsized enterprises pointed out the problem with the liquidity, and large companies declared guarantees and liquidity $(29.63 \%)$ as the most difficult criteria. 
Our research does have certain limitations, mostly related to the number of the respondents and its geographical focus. Nevertheless, we believe that our methodological approach is valuable and inspiring. In the nearest future we are planning to widen the monitored region and conduct a more extensive survey of the quality of the business environment in the V4 countries.

\section{ACKNOWLEDGEMENT}

This research paper is a part of the project "Financial risks of Small and Medium Enterprises in Slovakia" in the frame of the granting program of the Grant Agency of Academic Alliance under the Grant agreement number $1 / 2016$.

\section{REFERENCES}

Adamowicz, M., \& Machla, A. (2016). Small and Medium Enterprises and the Support Policy of Local Government. Oeconomia Copernicana, 7(3), 405-437. doi: https://doi.org/10.12775/OeC.2016.024

Abor, J.Y., Agbloyor, E.K., \& Kuipo, R. (2014). Bank finance and export activities of Small and Medium Enterprises. Review of Development Finance, 4(2), 97-103.

Badulescu, D. (2012). SMEs financing: The Extend of Need and the Responses of Different Credit Structures. Theoretical and Applied Economics, 17(7), 25-36.

Beck, T., \& Demigruc-Kunt, A. (2006). Small and medium-size enterprises: Access to finance as a growth constraint. Journal of Banking \& Finance, 30(11), 2931-2943.

Beck, T., Demigruc-Kunt, A, \& Maksimovic, V. (2008). Financing patterns around the world: Are small firms different? Journal of Financial Economics, 89(3), 467-487.

Behr, P., \& Guttler, A. (2007). Credit Risk Assessment and Relationship Lendng: An Empirical Analysis of German Small and Medium-Sized Enterprises. Journal of Small Business Management, 45(2), 194-213.

Belanová, K. (2012) Investície, riziko a nezamenitel'nost' investícií: príklad automobilového priemyslu v Slovenskej republike. Journal of Economics, 60(2), 187-209.

Belás, J., \& Sopková, G. (2016). A Model of Entrepreneurial Orientation. Transformation in Business \& Economics, 15(2B (38B), 630-645.

Belás, J., Bilan, Y., Ključnikov, A., Vincúrová, Z., \& Machaček, J. (2015a). Actual Problems of Business Risk In Sme Segment. Case Study from Slovakia. International Journal of Entrepreneurial Knowledge, 3(1). doi: 10.1515/ijek2015-0010.

Belás, J., Ključnikov, A., Vojtovič, S., \& Sobeková-Májková, M. (2015b). Approach of the SME entrepreneurs to financial risk management in relation to gender and level of education. Economics and Sociology, 8(4), 32-42.

Belás J., Macháček J., Bartoš P., Hlawiczka R., \& Hudáková M. (2014). Business Risks and the Level of Entrepreneurial Optimism among SME in the Czech and Slovak Republic. Journal of Competitiveness, 6(2), 3041.

Belás, J., Vojtovič, S., \& Ključnikov, A. (2016). Microenterprises and Significant Risk Factors in Loan Process, Economics and Sociology, 9(1), 43-59. doi: 10.14254/2071-789X.2016/9-1/3

Bena, J., \& Ondko, P. (2012). Financial development and the allocation of external finance. Journal of Empirical Finance, 19(1), 1-25.

Bottazzi, G., Secchi, A., \& Tamagni, F. (2014). Financial constraints and firm dynamics. Small Business Economics, 42(1), 99-116.

Bougheas, S., Mizen, P., \& Yalcin, C. (2006). Access to external finance: Theory and evidence on the impact of monetary policy and firm-specific characteristics. Journal of Banking and Finance, 30(1), 199-227.

Delibasic, M. (2016). Hypothetical Matrix for Institutional Modeling of the Basis for Economic Development in the Countries of Southeast Europe. Montenegrin Journal of Economics, 12(2), 147-159. doi:10.14254/1800$5845.2016 / 12-1 / 9$ 
Dobeš, K., Kot, S., Kramoliš, J., \& Sopková, G. (2017). The Perception of Governmental Support in The Context of Competitiveness of SMEs in the Czech Republic. Journal of Competitiveness, 9(3), 34-50. doi: $10.7441 /$ joc.2017.03.03

Dong, Y., \& Men, Ch. (2014). SME financing in emerging markets. Emerging Markets Finance \& Trade, 50(1), $120-149$.

Draskovic, V., Popov, E., \& Peleckis, K.K. (2017). Modelling of Institutional Changes in Transition Countries - the Gap Between the Theory and Practice. Montenegrin Journal of Economics, 13(1), 125-140, doi:10.14254/18005845/2017.13-1.9

Dubravska, M. et al. (2015). Internationalization of Entrepreneurship-Motivating Factors: Case Study of the Slovak Republic. Acta Polytechnica Hungarica, 12(5), 121-133.

Freel, M. (2006). Are Small Innovators Credit Rationed? Small Business Economics, 28(1), 23-35.

Gambini, A., \& Zazzaro, A. (2013) Long-lasting bank relationships and growth of firms. SmallBusEcon, 40, 977-1007.

Henderson, J., \& Weiler, S. (2010). Entrepreneurs and job growth: probing the boundaries of time and space. Economic Development Quarterly, 24(1), 23-32.

Hernández-Cánovas, G., \& Martínez-Solano, P. (2010). Relationship lending and SME financing in the continental European bank-based system. Small Business Economics, 34(4), 465-482.

Cheng, M.E., \& Tang, Y. (2012). Research on the Small and Medium-sized Enterprises Financing Problems. Proceedings of the sixth international symposium - The development of small and medium-sized enterprises, Dec 15 - 19, 9397.

Irwin, D. \& Scott, J.M. (2010). Barriers faced by SMEs in raising bank finance. International Journal of Entrepreneurial Behavior and Research, 16(9), 245-259.

Ivanová, E. (2017). Barriers to the development of SMEs in the Slovak Republic. Oeconomia Copernicana, 8(2), 255272. doi: http://dx.doi.org/10.24136/oc.v8i2.16

Jakubec, V., Sobeková Majková, M., \& Solík, J. (2012). Potreby mladých podnikatelov a prekáǎky v ich podnikaní. ZMPS: Bratislava. ISBN 978-80-970916-4-4.

Jinjarak, Y., \& Wignaraja, W. 2016. An Empirical Assessment of the Export - Financial Constraint Relationship: How Different are Small and Medium Enterprises? World Development, 79(1), 152-163.

Karpak, B., \& Topcu, I. (2010). Small medium manufacturing enterprises in Turkey: an analytic network process framework for prioritizing factors affecting success. International Journal of Production Economics, 125, 60-70.

Klierova, M., \& Kutik, J. (2017). One stop government - strategy of public services for citizens and businesses in Slovakia. Administratie si Management Public, (28), 66-80.

Ključnikov, A., \& Belás, J. (2016). Approaches of Czech Entrepreneurs to Debt Financing and Management of Credit Risk. Equilibrium. Quarterly Journal of Economics and Economic Policy, 11(2), 343-365.

Koisova, E., Habanik, J., Virglerova, Z. \& Zoltan Rozsa, Z. (2017), SMEs Financing as an Important Factor of Business Environment in Slovak Republic Regions. Montenegrin Journal of Economics, 13(2), , 129-140, doi: $10.14254 / 1800-5845 / 2017.13-2.8$

Korcsmaros, E., Mura, L., \& Hevesi, A. (2016). Selected aspects of business networks. Actual Problems of Economics, 186(12), 147-156.

Kot, S. (2017). Funkcjonowanie małych i Średnich przedsiębiorstw w kontekście zarządzania łańcuchem dostaw. Przeglad Organizacji, 11, 3-11.

Kozubíková, L., Belás, J., Ključnikov, A., \& Virglerová, Z. (2015). Differences in Approach to Selected Constructs of Entrepreneurial Orientation in SME Segment Regarding the Selected Socio-Demographic Factors. Transformations in Business \& Economics, 14(3C (36C), 42-59.

Kozubíková, L., Homolka, L., \& Kristalas, D. (2017). The Effect of Business Environment and Entrepreneurs' Gender on Perception of Financial Risk in The Smes Sector. Journal of Competitiveness, 9(1), 36-50. doi:10.7441/joc.2017.01.03

Lazányi, K. (2014). Entrepreneurs of the future. Serbial Journal of Management, 9(2), 149-158. doi:10.5937/sjm9-6257

Majková, M. (2008). Možnosti financovania malých a stredných podnikov v SR (Analýza štandardného a alternatívneho financovania malých a stredných podnikov v podmienkach SR). Tribune: Brno. ISBN 978-80-7399-590-4.

Mercieca, S., Schaeck, K., \& Wolfe, S. (2009). Bank Market Structure Competition and SME Financing Relationship in European Regions. Journal of Financial Services Research, 36(2-3), 137-155. 
Meyer, D.F., \& Meyer, N. (2017). Management of small and medium enterprise (SME) development: An analysis of stumbling blocks in a developing region. Polish Journal of Management Studies, 16(1), 127-141. doi:10.17512/pjms.2017.16.1.11

NBS. (2014). The analysis of Slovak financial segment. Online: http://www.nbs.sk/ img/Documents/ Dohlad/ORM/Analyzy/protected/AnalyzaSFS2014.pdf

NBS. (2015). Analytical review. The estimation of the impact of credit supply restrictions on the real economy. Online: http://www.nbs.sk/ img/Documents/ komentare/AnalytickeKomentare/2015/AK19 uverove restrikcie. pdf

Neuberger, D., \& Räthke-Döppner, S. (2014). The role of demographic in small business loan pricing. Small Business Economics, 44(2), pp. 411-424.

Nuhiu, A., Hoti, A., \& Bektashi, M. (2017). Determinants of commercial banks profitability through analysis of financial performance indicators: evidence from Kosovo. Business: Theory and Practice, 18, 160-170. doi: https://doi.org/10.3846/btp.2017.017

Oliveira, B., \& Fortunato, A. (2006). Firm Growth and Liquidity Constraints: A Dynamic Analysis. Small Business Economics, 27(2-3), 139-156. doi:10.1007/s11187-006-0006-y

Pickernell, D., Packham, G., Jones, P., Miller, C., \& Thomas, B. (2011). Graduate entrepreneurs are different: They access more resources?. International Journal of Entrepreneurial Behaviour and Research, 17(2), 183-202.

Rabbani, K., \& Moossa, M. (2014). Non-accessibility of Bank Financing to Newly Established SMEs. Pakistan Business Review, 16(2), 293-305.

Rahman, A. R., Civelek, M. C., \& Kozubikova, L. K. (2016). Proactiveness, competitive aggressiveness and autonomy: a comparative study from the Czech Republic. Equilibrium. Quarterly Journal of Economics and Economic Policy, 11(3), 631-650. doi: http://dx.doi.org/10.12775/EQUIL.2016.028.

Riding, A., Orser, B.J., Spence, M., \& Belanger, B. (2012). Financing new venture exporters. Small Business Economics, 38(2), 147-163.

Rostamkalaei, A., \& Freel, M. (2015). The cost of growth: small firms and the pricing of bank loans. Small Business Economics, 46(2), 255-272.

SAV. Ekonomický ústav. (2008). Vývoj a perspektívy svetovej ekonomiky. Bratislava. ISBN 978-807144-166-3.

Shi, L. (2012). The Factors of Affecting Financing and Countermeasures Based on Asymmetric Information and Marginal Information Cost. Information and Business Intelligence, PTI 267, 672-677.

Simo, D., Mura, L., \& Buleca, J. (2016). Assessment of milk production competitiveness of the Slovak Republic within the EU-27 countries. Agricultural Economics (Crech Republic), 62(10), 482-492.

Slavec, A. (2014). Bank financing and trade credit use of Slovenian small firms: An empirical examination. Transformations in Business and Economics, 13(2), 91-101.

Sobeková Majková, M. (2011). Analýza bariér a faktorov financovania malých a stredných podnikov v SR (The analysis of barriers of SMEs financing). Journal of Economics, 59(10), 1028-1032.

Sobeková Majková, M. (2016) The Influence of the Selected Factors on Financial Risk Perception in Slovak SMEs. Actual Problems of Economics, 10(184), 121 - 130.

Spoz, A. (2014). Significance of the EU Funds in Investments of Small and Medium-Sized Enterprises. Oeconomia Copernicana, 5(4), 61-74. doi: http://dx.doi.org/10. 12775/OeC.2014.027

Steinerowska-Streb, I., \& Steiner, A. (2014). An Analysis of External Availability on SMEs Decision Making. Thunderbird International Business Review, 56(4), 373-386.

Virglerová, Z., Dobeš, K, \& Vojtovič, S. (2016). The Perception of the State's Influence on its Business Environment in the Small and Medium Size Enterprise segment in the Czech Republic. Administratie si Management Public, 26, 78-96.

Vos, E., Yeh, A. J.-Y., Carter, S., \& Tagg, S. (2007). The happy story of small business financing. Journal of Banking and Finance, 31(9), 2648-2672. doi: 10.1016/j.jbankfin.2006.09.011 